\title{
Selective nuclear transport of the Drosophila morphogen dorsal can be established by a signaling pathway involving the transmembrane protein Toll and protein kinase $A$
}

\author{
Jacqueline L. Norris and James L. Manley \\ Department of Biological Sciences, Columbia University, New York, New York 10027 USA
}

\begin{abstract}
Establishment of dorsal-ventral polarity in the early Drosophila embryo requires a concentration gradient of the maternal morphogen dorsal (dl). This concentration gradient is established by selective nuclear transport of $d l$ so that $d l$ protein is present only in ventral nuclei. The activity of 11 genes is required for $d l$ nuclear localization. One of these genes, Toll, encodes a transmembrane protein that appears to play the most direct role in regulating $d l$ localization. We have examined the effects of $T o l l$ on $d l$ in cotransfected Schneider cells to gain insight into the nature of the interaction between these proteins. We have found that Toll can enhance the nuclear localization of $d l$ and, independently, the ability of $d l$ to activate transcription once in the nucleus. We present evidence that the signaling pathway from Toll to $d l$ involves protein kinase $A(P K A)$ and that nuclear transport and activation of $d l$ results from phosphorylation of $d l$ by PKA. We discuss the significance of these results with respect both to Drosophila embryogenesis and to the regulation of the mammalian transcription factor NF- $\kappa$ B.
\end{abstract}

[Key Words: Drosophila morphogen; dorsal; Toll; protein kinase A]

Received December 30, 1991; revised version accepted June 24, 1992.

Establishment of dorsal-ventral $(\mathrm{D} / \mathrm{V})$ polarity in the Drosophila embryo requires the activities of several maternal genes, including 11 that comprise the dorsal group (for review, see Anderson 1989; Rushlow and Arora 1990 ). One member of this group is the D/V morphogen dorsal (dl), a protein that shares homology, over the amino-terminal 300 amino acids, with the proto-oncogene c-rel and the mammalian transcription factor NF$\kappa B$. This region includes a putative DNA-binding domain, a nuclear localization sequence (NLS), and a potential protein kinase A (PKA) phosphorylation site (Steward 1987; Ghosh et al. 1990; Kieran et al. 1990). The $d l$ protein is distributed in a concentration gradient over the embryo, with the highest levels present in ventral regions and progressively decreasing levels in dorsal regions (Steward et al. 1988). This gradient results from the selective nuclear transport of the $d l$ protein, which is uniformly cytoplasmic in the early embryo until cleavage cycle 10 when it is transported into ventral but not dorsal nuclei (Roth et al. 1989; Rushlow et al. 1989; Steward 1989|. Following its accumulation in the nucleus, $d l$ functions to influence the expression of several zygotic genes required for D/V polarity (for review, see Anderson 1987; Rushlow and Arora 1990).

The activity of the other dorsal group genes is essential for the proper localization of the $d l$ protein (Anderson and Nüsslein-Volhard 1986). In embryos that carry null mutations in any of these genes, ventral cells follow the developmental pathway of dorsal cells. The dorsalization of these embryos is the result of the absence of the $d l$ protein in ventral nuclei, which results in the improper expression of zygotic genes. The function of the dorsal group gene products is to establish the $d l$ nuclear protein gradient. Two of these genes, easter and snake, encode serine proteases (DeLotto and Spierer 1986; Chasan and Anderson 1989), suggesting that a cascade of interactions involving post-translational processing could result in the formation of the signal for $d l$ movement into ventral nuclei. This signal is most likely localized in the perivitelline space on the ventral side of the embryo and is transmitted to $d l$ through the product of the Toll gene (Hashimoto et al. 1988; Stein et al. 1991), which is localized uniformally in the embryo plasma membrane (Hashimoto et al. 1991). Genetic studies have shown that Toll is one of the last genes in the $\mathrm{D} / \mathrm{V}$ cascade, acting upstream of $d l$, and cytoplasmic injection experiments have shown that Toll is responsible for establishing polarity in the embryo by defining the position of the $\mathrm{D} / \mathrm{V}$ axis (Anderson et al. 1985a,b). These observations, along with the isolation of both dominant-ventralizing 
as well as recessive-dorsalizing alleles of Toll (Anderson et al. 1985a; Schneider et al. 1991), suggest that the Toll gene product plays a particularly critical role in regulating $d l$ localization. However, nothing is known about the mechanism by which Toll enhances nuclear transport of $d l$.

The Toll protein has a large extracellular domain that contains two blocks of leucine-rich repeats with adjacent cysteine-containing motifs (Hashimoto et al. 1988; Schneider et al. 1991) and a small cytoplasmic domain that is similar to the cytoplasmic domain of the interleukin-1 receptor (IL-1R) (Schneider et al. 1991). The overall structure of the Toll protein is most similar to the $\alpha$ chain of human platelet glycoprotein lb (GPIb), a receptor for von Willebrand factor and thrombin (Lopez et al. 1987; Hashimoto 1988). The leucine-rich repeat and cysteine-containing motif in GP1b are required for thrombin binding, suggesting that these regions in the Toll protein may serve as ligand-binding sites (Keith and Gay 1990). The importance of these regions in Toll is indicated by the finding that three of the strongest Tolldominant alleles contain point mutations in one of the cysteine-containing motifs (Schneider et al. 1991).

To study the mechanism of $d l$ nuclear transport we have used transient cotransfection assays in Drosophila Schneider cells. These cells contain no detectable endogenous $d l$ protein so the localization and activity of $d l$ produced from transfected templates can be readily observed (Rushlow et al. 1989). In this system, exogenously produced $d l$ protein was shown previously to be local- ized primarily in the cytoplasm at low concentrations of expression vector, but increasingly in the nucleus at higher concentrations. The $d l$ protein was also shown to activate expression of several reporter genes in a highly concentration-dependent manner (Rushlow et al. 1989). Here, we have used the cotransfection system as an assay to show that Toll can bring about selective nuclear transport of $d l$ in Schneider cells, ruling out an absolute requirement of factors unique to the early embryo. Additional experiments indicate that the mechanism appears to involve phosphorylation of $d l$ by activated PKA.

\section{Results}

We have used transient cotransfection assays in Drosophila Schneider cells to study the activity and nuclear transport of the $d l$ protein. Figure 1 describes the principal plasmid constructs used in these studies. The cDNAs encoding $d l$ and Toll, as well as PKA, were each cloned into an actin $5 \mathrm{C}$ expression vector so that their expression was driven by the actin $5 \mathrm{C}$ promoter, a strong promoter in Schneider cells (Han et al. 1989). The activity of the $d l$ protein was measured by its ability to activate expression of the chloramphenicol acetyltransferase (CAT) gene from a 200-bp fragment $(-196$ to +39$)$ of the Drosophila zen promoter (zen-CAT200). The $d l$ protein was shown previously to activate CAT expression from this promoter in a strongly concentration-dependent manner, from 2- to >1000-fold (Rushlow et al. 1989). This promotor fragment contains no detectable $d l$-bind
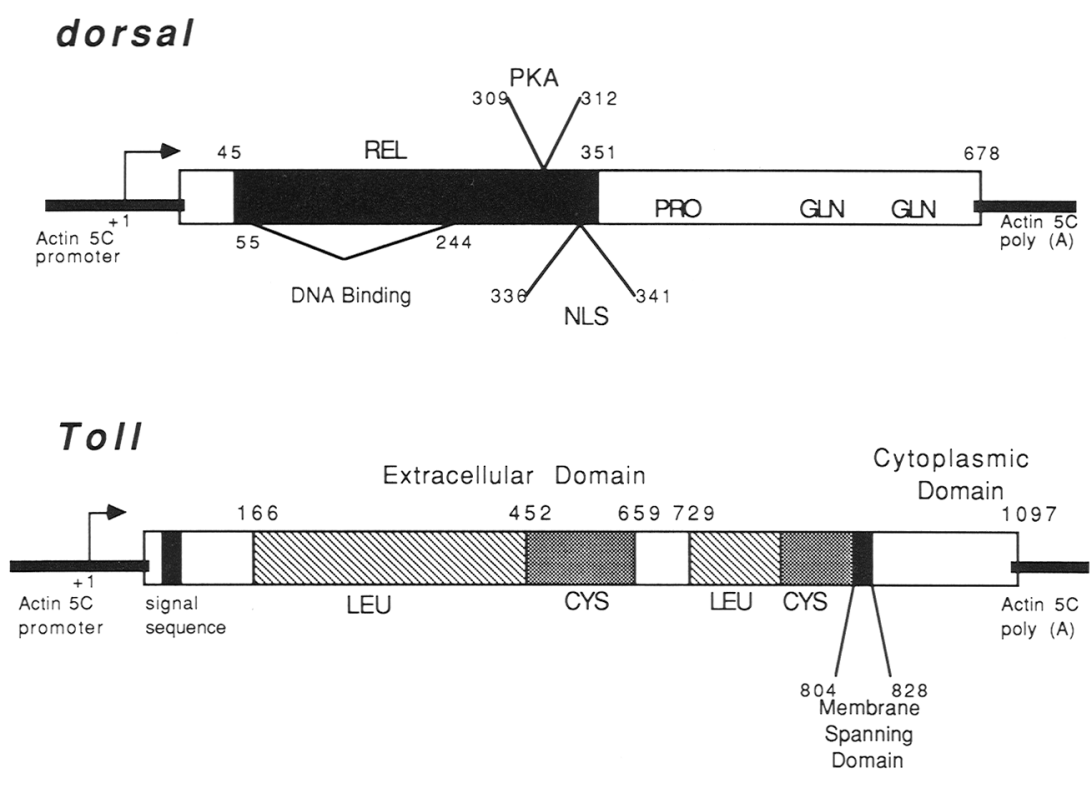

$z e n-\mathrm{CAT} 200$

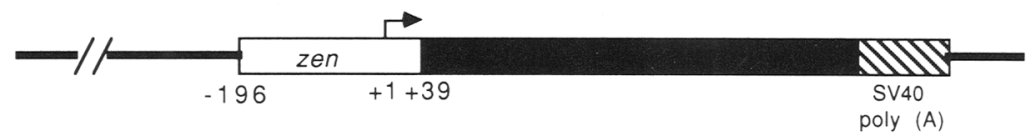

Figure 1. Structures of plasmid constructs. The $d l$ protein shares homology with the rel and NF- $\mathrm{BB}$ proteins over the amino-terminal 300 amino acids /solid area). This region contains a conserved PKA phosphorylation site, a NLS, and a putative DNA-binding domain. The carboxyl terminus contains proline (PRO)- and glutamine (GLN)-rich regions. Numbers refer to amino acid residues. The Toll protein has a large extracellular domain of 804 amino acids, with two blocks of leucine-rich repeats (LEU), adjacent cysteine motifs (CYS), and a small (269-amino-acid) cytoplasmic domain. Solid vertical rectangles indicate the locations of signal sequence and membrane-spanning domain. Numbers refer to amino acid residues. The zen-CAT200 reporter plasmid contains $\sim 200 \mathrm{bp}$ from the zen promoter $(-196$ to +39$)$ controlling expression of the CAT gene. The pUC vector also contains $\mathrm{SV} 40$ poly(A) sequences. 
ing sites, and the mechanism by which $d l$ mediates activation is not known (see Discussion). However, for the purposes of the current study, this reporter construct provided an excellent assay for $d l$ activity.

\section{Activity of the $\mathrm{dl}$ protein in the presence of Toll}

Genetic studies have identified the Toll protein as the most likely candidate for receiving and transmitting the signal that results in movement of the $d l$ protein into ventral nuclei (for review, see Anderson 1989). To investigate the underlying mechanism, we wished to determine whether a functional interaction between these two proteins could be observed in a simplified system, that is, cultured cells. To this end, we cotransfected different concentrations of expression vectors containing Toll (Act-Tl) or dl (Act-dl) cDNAs, along with zenCAT200, into Schneider cells and assayed the resultant CAT activities. All increases in CAT activity are presented relative to that measured from transfections that contained an equal amount of the actin $5 \mathrm{C}$ expression vector without a cDNA insert and were also normalized to an internal-control plasmid (see Materials and methods). Transfections containing the $d l$ expression vector alone showed that, as observed previously (Rushlow et al. 1989), dl activates CAT expression in a concentration-dependent manner, with strong activations observed at concentrations $>1.0 \mu \mathrm{g}$ and weaker, more gradually increasing activations at concentrations from 0.1 to $1.0 \mu \mathrm{g}$ (Fig. 2, and results not shown).

Cotransfection of Act- $T l$ with Act-dl resulted in significant enhancement of CAT expression (Fig. 2). The greatest effects were seen at moderate $d l$ concentrations, where CAT activities were correspondingly modest. Thus, an activation of approximately ninefold was observed with $0.3 \mu \mathrm{g}$ of Act-dl, and activation was approximately sixfold with $0.4 \mu \mathrm{g}$. In numerous independent experiments, we have always detected activations between 6- and 12-fold with optimal concentration of Act$d l$. At lower amounts of Act-dl, activations induced by the expression of Toll were reproducibly weaker, perhaps reflecting a subthreshold concentration of $d l$ protein in the transfected cells. At high $d l$ concentrations $(>1.0$ $\mu g$, no significant activation was observed with cotransfection of Act- $T 1$ (results not shown), perhaps reflecting in part an inability to introduce enough Act- $T$ I to further enhance the strong activations brought about by Act-dl alone.

Several controls indicated that the observed increases resulted from a specific interaction involving $d l$ and Toll. For example, cotransfection of Act-Tl with zen-CAT200 alone did not affect CAT activity (Fig. 2). Likewise, cotransfections of Act-Tl along with expression vectors encoding other Drosophila transcriptional activators (prd, z2, zen), together with their appropriate promoterCAT reporter constructs (Han et al. 1989), did not alter the CAT expression observed with these expression vectors alone (results not shown). Thus, the enhancement of CAT activity induced by Toll appears to reflect a specific interaction with $d l$. Also, analysis of $d l$ protein concen-

\begin{tabular}{|c|c|c|}
\hline dorsal & - Toll & + Toll \\
\hline- & 1 & 1.1 \\
\hline 0.1 & 2.2 & 3.3 \\
\hline 0.2 & 4.1 & 16 \\
\hline 0.3 & 3.6 & 32 \\
\hline 0.4 & 5.6 & 34 \\
\hline 0.6 & 16 & 54 \\
\hline 1.0 & 50 & 168 \\
\hline
\end{tabular}

Figure 2. Activity of wild-type $d l$ in the presence of Toll. Schneider cells were cotransfected with the indicated amount of $d l$ expression vector $(\mu \mathrm{g}), 3.0 \mu \mathrm{g}$ of the zen-CAT200 reporter plasmid, and either pAct5C $(-$ Toll $)$ or Toll expression vector $(+$ Toll $)$ to bring the final concentration of expression vector to $5.0 \mu \mathrm{g}$. All transfections were normalized for differences in transfection efficiency by using copia $\beta$-gal as an internal control. The CAT activities shown are expressed relative to cotransfections containing $5.0 \mu \mathrm{g}$ of actin $5 \mathrm{C}$ expression vector without an insert.

tration by Western blotting showed that cotransfection of Toll did not affect the accumulation of $d l$ protein /data not shown), ruling out the possibility that the effects of Toll were the result of increased levels of $d l$.

\section{Expression of Toll results in increased nuclear} localization of the $\mathrm{dl}$ protein

To determine whether the increased activation of CAT expression by $d l$ in the presence of Toll reflected increased nuclear localization of the $d l$ protein, cells were transfected with $0.4 \mu \mathrm{g}$ of Act-dl alone or $0.4 \mu \mathrm{g}$ of Act$d l$ plus $4.6 \mu \mathrm{g}$ of Act-Tl, fixed, and stained with anti-dl antibodies. Representive cells from each transfection are shown in Figure 3a. Cells that received Act-dl alone produced the $d l$ protein that was localized predominantly in the cytoplasm (Fig. 3a,A). In contrast, $d l$ protein was found in both the nucleus and cytoplasm, or in some cells predominantly in the nucleus, in cells cotransfected with Act-dl and Act-Tl (Fig. 3a,B). A population of stained cells that were transfected with $0.4 \mu \mathrm{g}$ of Act$d l$ and increasing amounts of Act- $T l$ were counted for cytoplasmic, nuclear and cytoplasmic, or nuclear localization, and the results are presented in Figure $3 \mathrm{~b}$. As the concentration of Act- $T 1$ was increased, the number of cells with protein in both the cytoplasm and nucleus, or predominantly in the nucleus, increased by almost 

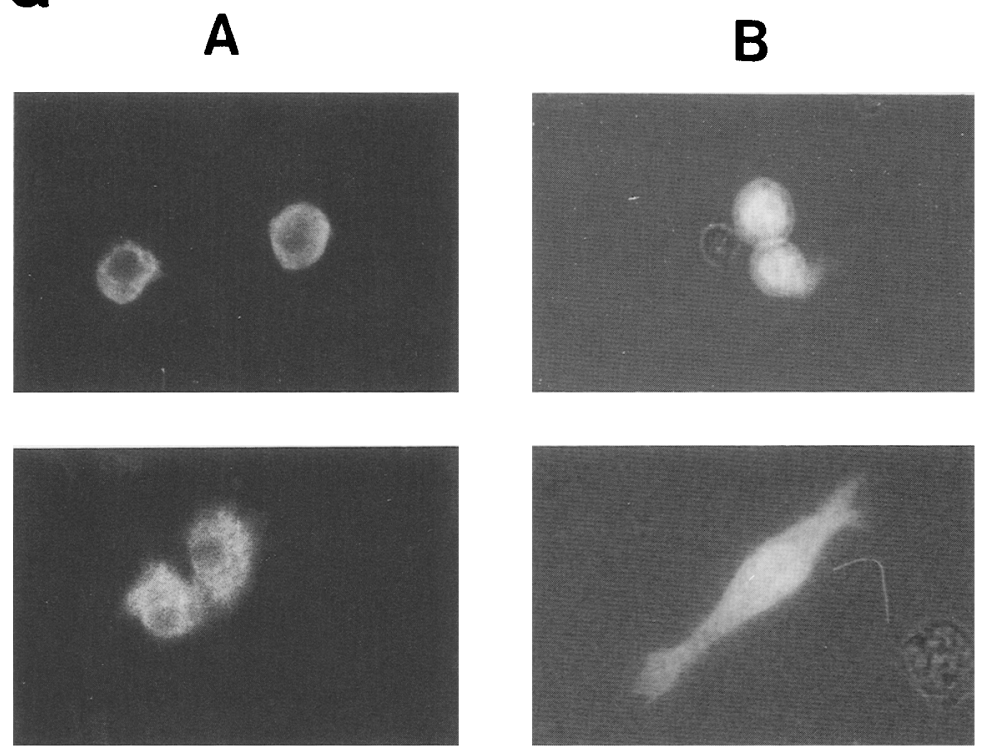

b

\begin{tabular}{|c|c|c|c|}
\hline Loll & Cytoplasm & $\begin{array}{c}\text { Cytoplasm } \\
\text { Nucleus }\end{array}$ & Nucleus \\
\hline 0 & 75 & 20 & 5 \\
\hline 1.0 & 78 & 22 & - \\
\hline 3.0 & 45 & 33 & 22 \\
\hline 4.0 & 50 & 38 & 12 \\
\hline 4.7 & 32 & 44 & 24 \\
\hline
\end{tabular}

Figure 3. Subcellular localization of $d l$ in the presence of Toll $|a|$ Schneider cells were transfected with $0.3 \mu \mathrm{g}$ of $d l(A)$ or $0.3 \mu \mathrm{g}$ of $d l$ plus $4.7 \mu \mathrm{g}$ of Toll $|B|$ and stained with anti-dl antibodies and TRITC-conjugated secondary antibodies. The $d l$ protein accumulates predominantly in the cytoplasm of transfected cells in the absence of Toll. The $\mathrm{dl}$ protein is found in the nucleus as well as the cytoplasm of cells transfected with Toll. (b) Schneider cells were cotransfected with $0.3 \mu \mathrm{g}$ of $d l$ and the indicated amounts of Toll expression vector $(\mu \mathrm{g})$ and stained with anti-dl and TRITC-conjugated secondary antibodies. At least $50 \mathrm{dl}$-expressing cells from each transfection were counted and scored for staining of the cytoplasm, the nucleus, or both the cytoplasm and nucleus. The percentage of cells in each category is shown.

threefold. These findings suggest that Toll functions to aid in relocalization of the $d l$ protein from the cytoplasm to the nucleus of Schneider cells, analogous to its role in the early embryo.

\section{The effect of Toll on $\mathrm{dl}$ mutants}

Several $d l$ mutants were analyzed to identify regions of the protein required for activity and regulation of nuclear localization. Figure 4a describes these mutants and lists the activity and localization observed in transfections containing $1.0 \mu \mathrm{g}$ of Act-dl, but in the absence of Toll. One of these mutants, $d l 3$, has been described previously as $d 1-561$, and transfections with this mutant showed that the carboxyl terminus is essential for cytoplasmic retention of $d l$ (Rushlow et al. 1989). Deletion of (dl7), or point mutations in $(d l 8)$, the nuclear localization signal (NLS), resulted in restriction of $d l$ to the cytoplasm, showing that the NLS is required for nuclear localization. Deletion of the carboxy-terminal unique region (dI4), or part of the rel homology region (dl6), resulted in a loss of $d l$ activity even though these proteins were constitutively localized in the nucleus, indicating that these regions are required both for activity and for cytoplasmic retention. In contrast, the subcellular localization of $d 15$, which lacks the DNA-binding region (Ip et al. 1991) and is essentially inactive, is similar to wild type, indicating that these sequences are not necessary for cytoplasmic retention.

These mutants were then used to examine regions of dl required for response to Toll. Figure $4 \mathrm{~b}$ presents the results of cotransfection of several of the $d l$ mutant expression vectors with Act- $T$ l. In cotransfections containing any of the $d l$ mutants that were inactive by themselves, no increase in CAT activity was seen when Toll was present $(d 14, d 15, d 16, d 17, d 18)$. These results show, for example, that the NLS is necessary for Toll responsiveness. Unexpected results were obtained with the $d 13$ mutant, which lacks 117 carboxy-terminal amino acids but retains some activity $(\sim 30 \%)$ and is constitutively nuclear (Rushlow et al. 1989). Cotransfections of $0.4 \mu \mathrm{g}$ of Act-dl3 with $4.6 \mu \mathrm{g}$ of Act- $T l$ resulted in enhancement of CAT expression by $\sim 15$-fold, an activation significantly greater than that observed for wild-type $d l$. As $d l 3$ is tightly localized in the nucleus in the absence of Toll, this finding indicates that Toll can affect $d l$ in a manner independent of its ability to direct $d l$ to the nucleus, and raises the possibility that Toll expression can result in direct modification of $d l$. As mentioned above, further deletion of the carboxyl terminus (d14) resulted in a protein that, by itself, was totally nuclear, inactive, and not influenced by the addition of Toll. However, when $d l 4$ was fused to the activation domain from the Drosophila z2 homeo box protein (Han et al. 1989), a 
a
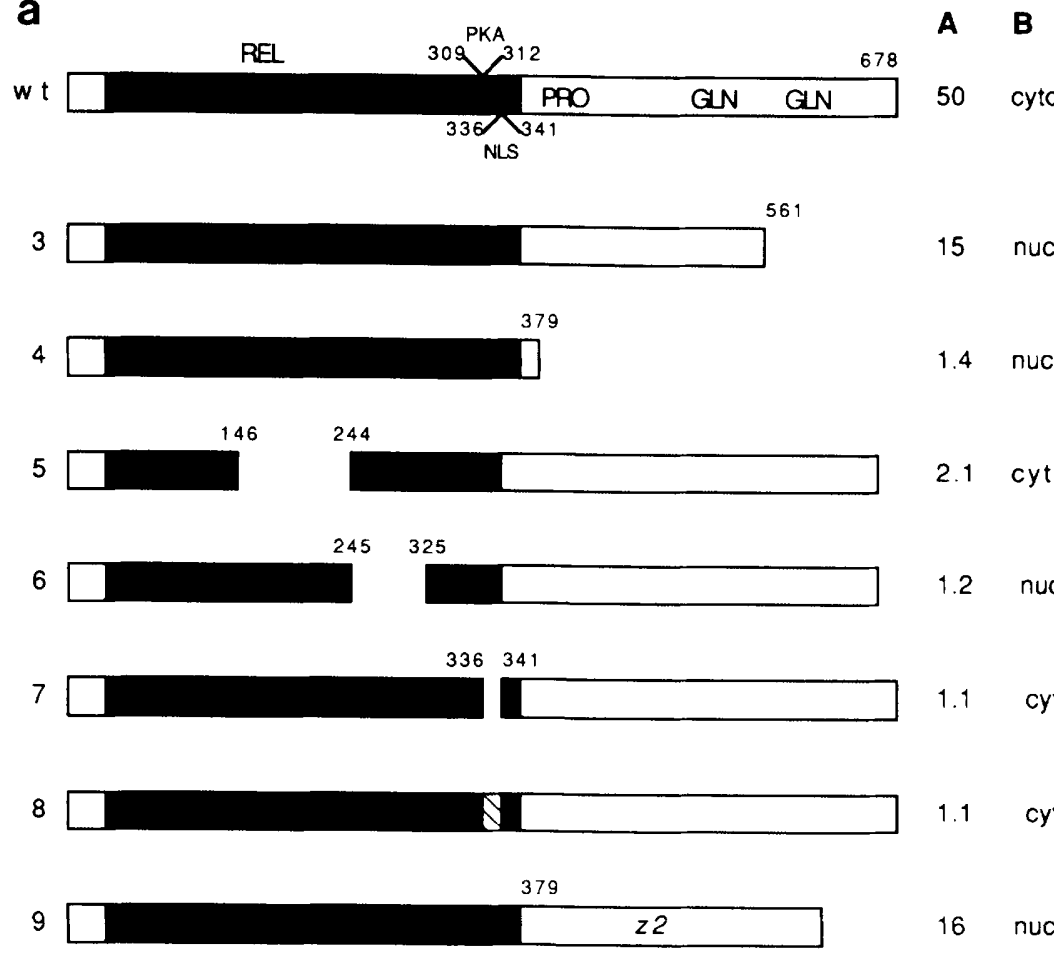

\begin{tabular}{|c|c|c|c|c|c|}
\hline \multirow{2}{*}{1.4} & \multirow{2}{*}{ nuc } & \multicolumn{2}{|c|}{ dorsal } & -Toll & + Toll \\
\hline & & \multirow{2}{*}{$w t$} & 0.4 & 4.8 & 38 \\
\hline \multirow{3}{*}{2.1} & \multirow{3}{*}{ cyto } & & 1.0 & 50 & 168 \\
\hline & & 3 & 0.4 & 2.3 & 33 \\
\hline & & & 1.0 & 15 & 50 \\
\hline \multirow[t]{2}{*}{1.2} & \multirow[t]{2}{*}{ nuc } & \multirow{2}{*}{4} & 0.4 & 1.2 & 1.5 \\
\hline & & & 1.0 & 1.4 & 2.3 \\
\hline \multirow[t]{2}{*}{1.1} & \multirow[t]{2}{*}{ cyto } & 5 & 1.0 & 2.1 & 2.2 \\
\hline & & 6 & 1.0 & 1.2 & 1.3 \\
\hline \multirow{3}{*}{1.1} & \multirow{3}{*}{ cyto } & \multirow{2}{*}{7,8} & 0.4 & 1.3 & 2.1 \\
\hline & & & 1.0 & 1.1 & 1.6 \\
\hline & & \multirow{2}{*}{9} & 0.4 & 4.4 & 10 \\
\hline 16 & nuc & & 1.0 & 16 & 29 \\
\hline
\end{tabular}

Figure 4. Subcellular localization and activity of $d l$ mutants alone and in the presence of Toll. $|a|$ The top line indicates the region of rel homology (solid area), the NLS, the conserved PKA phosphorylation site, and the approximate position of proline (PRO) and glutamine (GLN) regions of the wild-type $d l$ protein. The regions deleted in the mutants are shown. Numbers refer to amino acid residues. Schneider cells were cotransfected with $1.0 \mu \mathrm{g}$ of the indicated $d l$ expression vector, $4.0 \mu \mathrm{g}$ of the actin $5 \mathrm{C}$ expression vector without the $d l$-coding region, and $3.0 \mu \mathrm{g}$ of the zen-CAT200 reporter plasmid. The predominant location of the protein in the cytoplasm (CYTO), the nucleus (NUC), or both is shown in column $A$. The ability of the protein to activate CAT expression is shown in column $B$. The CAT activities are expressed relative to cotransfections containing $5.0 \mu \mathrm{g}$ of actin $5 \mathrm{C}$ expression vector without the $d l$-coding region. (b) Schneider cells were cotransfected with the indicated amount of $d l$ expression vector $(\mu \mathrm{g}), 3.0 \mu \mathrm{g}$ of the zenCAT200 reporter plasmid, and either pAct5C (-Toll) or Toll expression vector $(+$ Toll) to bring the final concentration of expression vector to $5.0 \mu \mathrm{g}$. The $\mathrm{dl}$ mutants are referred to by the numbers used in $a$. Mutants 7 and 8 behave essentially identically, and representive values are shown.

protein displaying low but significant activity was produced (dl9; see Fig. 4a). Cotransfection of Act-dl9 with Act-Tl enhanced the activity of the fusion protein (which is constitutively nuclear), but only by approximately twofold, suggesting that sequences in the $d l$ unique region are in some way required for maximal activation by Toll.

\section{Effect of Toll mutations on activation of $\mathrm{dl}$}

To begin to determine regions of Toll that are necessary for its function, we constructed and analyzed several Toll deletion mutants. Figure 5a details the structures of these mutants, and Figure $5 \mathrm{~b}$ displays the results of cotransfections with Act-dl. A deletion of all but the amino-terminal 274 amino acids (RV) of Toll resulted in a total loss of Toll activity as measured by its ability to enhance the activation of CAT expression of $d l$ from zen-CAT200. A small deletion (122 amino acids) into the carboxyl terminus (StuI) also abolished Toll activity, indicating that the intracytoplasmic domain is essential for activity. Because some receptors can be activated by deletion of their extracellular domains (see Discussion), we deleted most of the extracellular domain of Toll (T1520) to determine whether this might activate Toll. However, this deletion had no effect on Toll activity, as approximately equal CAT activities were detected in cotransfections with Act-Tl520 and Act-Tl. This finding suggests that ligand binding is not required for Toll activation in Schneider cells (see Discussion).

Both dominant-ventralizing and recessive-dorsalizing alleles of Toll have been identified (Anderson et al. 1985a), and several of these alleles have been cloned and grouped into three classes (Schneider et al. 1991). One class consists of recessive alleles that result from point mutations in the cytoplasmic domain. This is consistent with our observation that an intact cytoplasmic domain is required for Toll activity. Another class contains dominant alleles that are amino-terminal truncations, although these ventralize only in the presence of wild-type Toll. The final class are dominant alleles that ventralize the embryo by facilitating nuclear transport of $\mathrm{dl}$ throughout the embryo (Roth et al. 1989; Steward 1989). The strongest of these is $T 1^{10 b}$ (Erdélyi and Szabad 1989), 

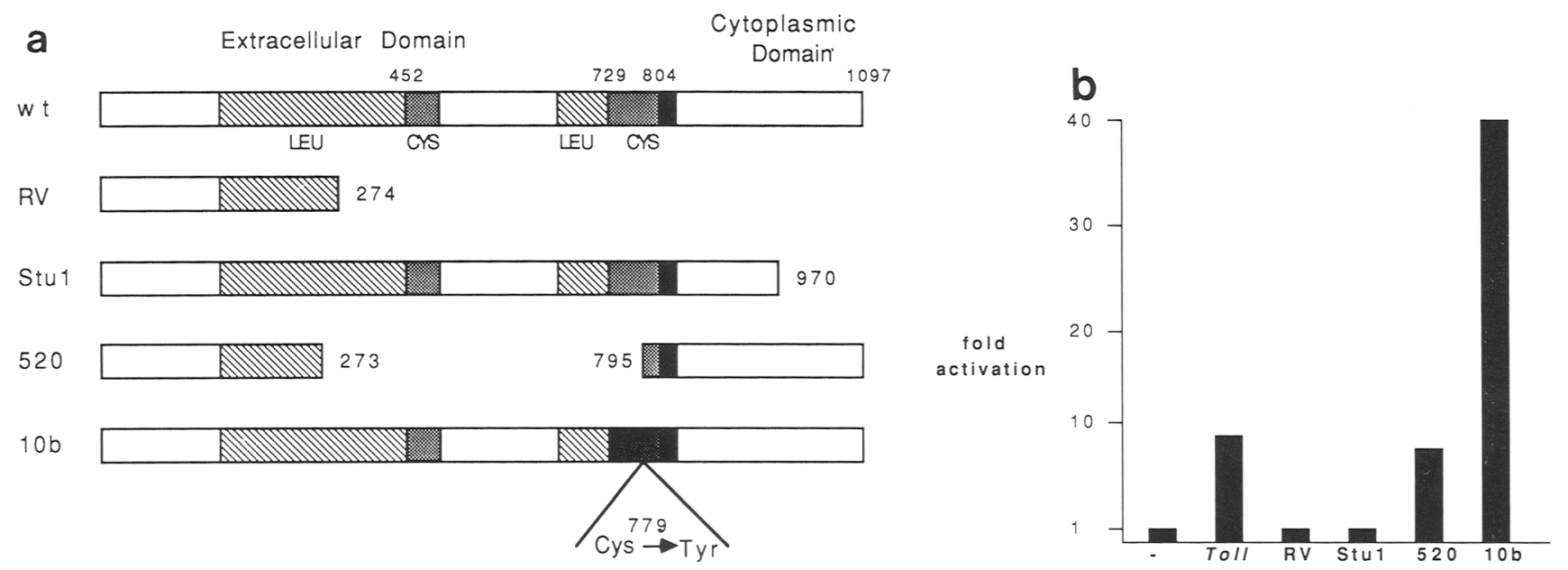

Figure 5. The effect of Toll mutants on $d l$ activity. $(a)$ The extracellular and cytoplasmic domains, as well as the leucine (LEU)- and cysteine (CYS)-rich regions are indicated on wt Toll, and regions deleted in the mutants are shown. Numbers refer to amino acid residues. The site of the $T l^{10 b}$ mutation is at residue 779 , a change of cysteine to tyrosine. $(b)$ Schneider cells were cotransfected with $0.4 \mu \mathrm{g}$ of $d l$ expression vector, $3.0 \mu \mathrm{g}$ of the zen-CAT200 reporter plasmid, and either $4.6 \mu \mathrm{g}$ of pAct5C $(-T o l l)$ or $4.6 \mu \mathrm{g}$ of the indicated Toll expression vector (+ Toll). Fold activation is presented as the increase in CAT activity relative to the value from the cotransfection lacking a Toll expression vector.

which contains a single amino acid change of a cysteine residue to tyrosine at position 779 (Schneider et al. 1991). Although the mechanism by which this single residue change results in constitutive nuclear localization of $d l$ in the embryo is not known, its existence offers a test of the physiological relevance of the cell culture assay that we have used to study Toll function. To address this, we cotransfected a construct expressing $T I^{10 b}$ together with Act-dl and zen-CAT200. Expression of $T 1^{10 b}$ resulted in a 40 -fold increase in $\mathrm{dl}$ activity, or approximately fivefold greater than that obtained with wild-type Toll (Fig. $5 \mathrm{~b})$, providing strong evidence that the mechanism by which Toll activates $d l$ in Schneider cells is similar to the mechanism operative in the early embryo.

\section{Expression of PKA results in the enhancement of $\mathrm{dl}$ activity and nuclear localization}

The $d l$, NF- $\mathrm{kB}$, and rel proteins all contain a conserved PKA phosphorylation site directly upstream of their NLSs (Steward 1987; Ghosh et al. 1990; Kieran et al. 1990). Mutations in the v-rel PKA site can reduce or abolish the ability of the protein to transform chicken spleen cells while mutations in the c-rel PKA site can alter the subcellular localization of the protein (Mosialos 1991). A mutational analysis of the NF- $k B$ PKA site has not been reported, but the effects of several protein $\mathrm{ki}$ nases on NF- $\mathrm{kB}$ activity in vitro has been tested (Ghosh and Baltimore 1990). Protein kinase $C(P K C)$ was shown to be most effective in activating NF- $\mathrm{KB}$ DNA-binding, by disrupting NF- $\mathrm{kB} / \mathrm{I} \mathrm{KB}$ complexes, and PKA was also shown to activate NF- $\mathrm{B}$, although not as effectively as PKC. While the mechanism of PKC activation was shown to involve direct phosphorylation of $\mathrm{I}_{\kappa} \mathrm{B}$, inhibiting its ability to bind NF- $\mathrm{kB}$, PKA did not phosphorylate
I $\mathrm{B}$, suggesting that it activates NF- $\mathrm{B}$ by a different mechanism. Given these observations, the conservation of the PKA site in all rel family members, and our finding that Toll enhances $d l$ activity independent of subcellular localization, we wished to determine whether PKA plays a role in $d l$ activation by Toll, perhaps by direct phosphorylation of $d l$.

We first asked whether $d l$ activity could be influenced by the expression of exogenous PKA. To this end, a cDNA encoding the Drosophila PKA catalytic subunit (Kalderon and Rubin 1988) was cloned into the actin 5C expression vector (Act-PKA), and this construct was cotransfected into Schneider cells together with Act-dl and the zen-CAT200 reporter. Figure 6a displays the CAT activities obtained for Act-dl concentrations from 0.1 to $1.0 \mu \mathrm{g}$ with Act-PKA. As with Act-Tl, expression of Act-PKA enhanced the ability of $d l$ to activate CAT expression. Although the responses obtained with both proteins were similar, PKA activated $d l$ somewhat more efficiently than Toll. Activations $>15$-fold were obtained with PKA, compared with $\sim 8$-fold with Toll.

To investigate the regions of $d l$ required for PKA activation, we tested the $d l$ mutants shown in Figure 4a in cotransfections with Act-PKA and the results are presented in Figure 6b. As with Act- $T$, those mutants that lacked activity by themselves were not affected by the expression of PKA. However, the constitutively nuclear dl3 was activated by PKA, showing that PKA, like Toll, affects both $d l$ activity in the nucleus and $d l$ nuclear localization (see below). Act-PKA was also cotransfected with Act-prd, Act-z2, and Act-zen, along with their appropriate promoter-CAT constructs, and found not to affect the activations detected with these proteins alone (results not shown). Therefore, the effect of PKA is specific for $d l$ and requires a $d l$ protein that retains some 


\begin{tabular}{|c|c|c|}
\hline dorsal & -PKA & +PKA \\
\hline- & 1 & 1.3 \\
\hline 0.1 & 1.6 & 16 \\
\hline 0.2 & 2.4 & 20 \\
\hline 0.3 & 2.7 & 47 \\
\hline 0.4 & 3.5 & 37 \\
\hline 0.6 & 18 & 65 \\
\hline 1.0 & 35 & 140 \\
\hline
\end{tabular}

\begin{tabular}{|c|c|c|}
\hline dorsal & -PKA & +PKA \\
\hline$w \mathrm{t}$ & 35 & 140 \\
\hline 3 & 8.7 & 71 \\
\hline 4 & 2.5 & 2.1 \\
\hline 5 & 0.5 & 1.5 \\
\hline 7.8 & 1.1 & 1.2 \\
\hline 9 & 12 & 13 \\
\hline
\end{tabular}

Figure 6. The effect of PKA on wild-type and mutant $d l$ activity. (a) Schneider cells were cotransfected with the indicated amount of $d l$ expression vector, $3.0 \mu \mathrm{g}$ of the zen-CAT200 reporter plasmid, and either pAct5C $(-\mathrm{PKA})$ or PKA expression vector $(+\mathrm{PKA})$ to bring the final concentration of expression vector to $5.0 \mu \mathrm{g}$. The activation values are expressed relative to cotransfections containing the actin $5 \mathrm{C}$ expression vector without an insert. $(b)$ Schneider cells were transfected with $1.0 \mu \mathrm{g}$ of $d l, 3.0 \mu \mathrm{g}$ of the zen-CAT200 reporter plasmid, and either $4.0 \mu \mathrm{g}$ of pAct5C (-PKA) or $4.0 \mu \mathrm{g}$ of PKA expression vector (+ PKA). The $d l$ mutants are referred to by the numbers used in Fig. $4 \mathrm{a}$.

activity and has an intact rel homology region, that is, the requirements for $d l$ activation by PKA and Toll appear to be identical.

To determine whether expression of PKA also increased the nuclear localization of $d l$, cells were transfected with $0.4 \mu \mathrm{g}$ of Act-dl alone (Fig. 7, panel A) or 0.4 $\mu \mathrm{g}$ of Act-dl plus $4.6 \mu \mathrm{g}$ of Act-PKA (panel B), fixed, and stained with anti-dl antibodies. Figure 7 presents pictures of representive cells from each transfection and shows that the expression of PKA resulted in an increased nuclear localization of $d l$. dl nuclear localization induced by PKA was more substantial than that observed with Toll. In the presence of PKA, $\sim 50 \%$ of the transfected cells showed strong nuclear staining compared with $25 \%$ showing predominantly nuclear staining in the presence of Toll.

\section{Expression of a protein kinase inhibitor prevents activation of $\mathrm{dl}$ by Toll}

The above results support the hypothesis that Toll activates $d l$ by a mechanism involving PKA. To address this idea further, we tested the effect of the inhibitor protein of PKA (PKi) on dl activity in the presence of Toll. PKi has been analyzed in some detail, and peptide fragments with inhibitory activity have been isolated (Cheng et al. 1985; for review, see Kemp et al. 1988). The PKi peptides specifically inhibit cAMP-dependent protein kinase by binding to the catalytic subunit (for review, see Walsh and Glass 1991). An actin 5C construct containing 26 amino acid residues of $\mathrm{PKi}$ fused to $l a c Z$-coding sequences, Act-lacZPKi, was cotransfected with Act-dl and Act- $T$, and the resultant CAT activities were measured (see Materials and methods). This PKi construct encodes a fusion protein containing the 20-amino-acid peptide that has been shown to be the most potent inhibitor of PKA (Cheng et al. 1985). Coexpression of ActlacZPKi nearly abolished the enhancement of $d l$ activity brought about by Toll (Fig. 8). This inhibition was specific for $d l$ as the CAT activities induced by $z 2$ or prd were not altered by the addition of PKi /results not shown). Inhibition was the result of the PKi moiety in the lacZ fusion protein, as identical amounts of an Actlac $Z$ expression vector did not affect $d l$ activity (Fig, 8). These results provide strong evidence that enhancement of $d l$ activity induced by Toll involves activation of PKA.

Mutations in the PKA phosphorylation site of $\mathrm{dl}$ affect $\mathrm{dl}$ protein localization and activity in the presence of Toll and PKA

To determine whether activation of $d l$ by Toll and PKA is dependent on the Il PKA site, we mutated the presumed site of phosphorylation, the serine (S) residue at position 312 . We first changed this $S$ residue to glutamine $(Q)$ to create a site that should not be phosphorylated by PKA. This mutant, Act-dlQ, was then cotransfected with Act-Tl or Act-PKA, and the resulting CAT activities are shown in Figure 9a. Mutation of the PKA phosphorylation site resulted in only a slight reduction (less than twofold) in the activity of $d l$ alone. However, the activation of CAT expression by $d l \mathrm{Q}$ in the presence of either Toll or PKA was reduced significantly relative to wild-type $d l$, in each case by as much as a factor of 10 , providing strong evidence that the dl PKA site plays an important roll in Toll-mediated regulation of $d l$ activity.

To determine whether the decreased activity of $d l Q$ in the presence of PKA or Toll reflected an inability of the mutant protein to be translocated to the nucleus, cells transfected with Act-dlQ alone (Fig. 9b, panel A), or with Act-Tl (not shown) or Act-PKA (panel B) were fixed 

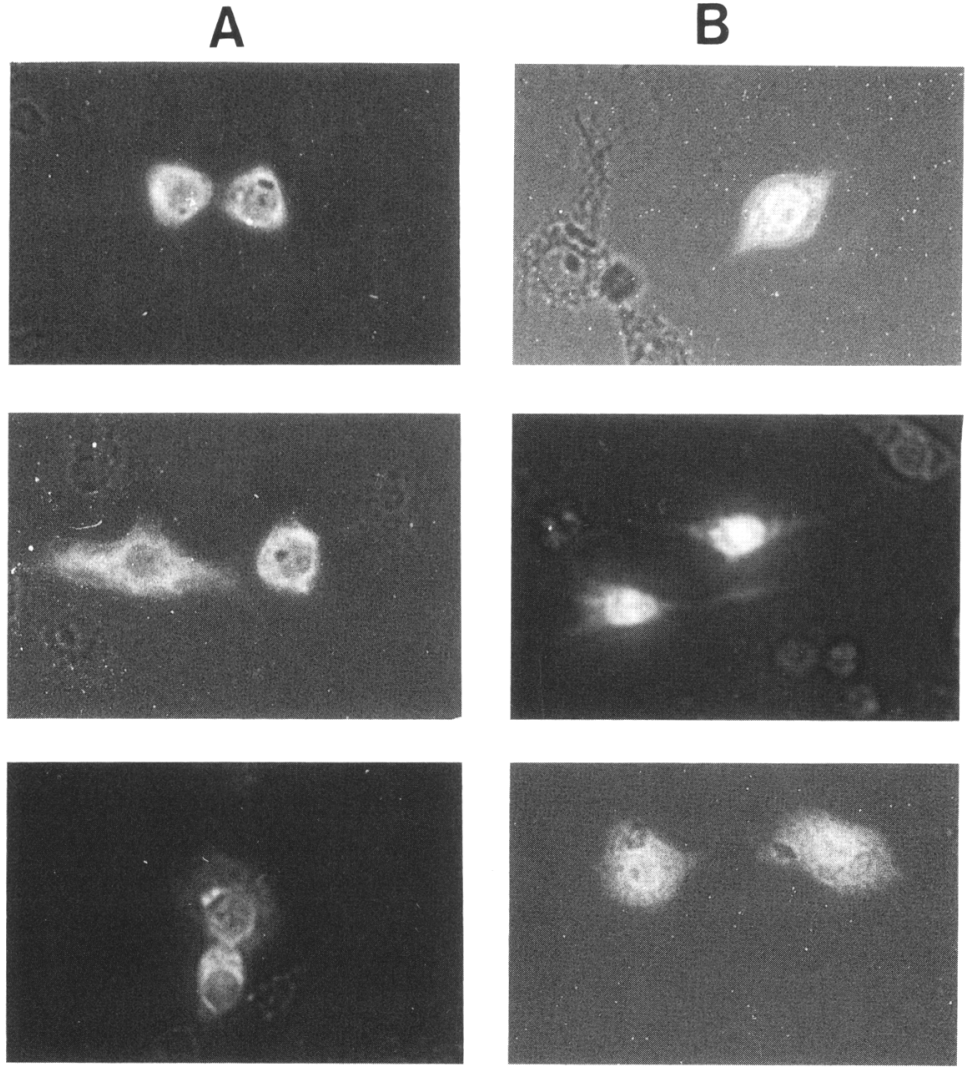

Figure 7. Subcellular localization of $d l$ in the presence of PKA. Schneider cells were transfected with 0.3 $\mu \mathrm{g}$ of $d l(A)$ or $0.3 \mu \mathrm{g}$ of $d l$ plus $4.7 \mu \mathrm{g}$ of PKA $(B)$ and stained with anti-dl and TRITC-conjugated secondary antibodies. The $d l$ protein accumulates predominantly in the cytoplasm of transfected cells in the absence of $\operatorname{PKA}(A)$. The $d l$ protein is found predominantly in the nucleus of cells transfected with PKA $(B)$. and stained with anti-dl antibodies, and pictures of representative cells are shown. These experiments show that $d l Q$, unlike wild-type $d l$, was not transported effectively to the nucleus in the presence of Toll or PKA (panel B), indicating that the dl PKA site is critical for regulated nuclear transport of the $d l$ protein.

We then wished to determine the effect of placing a

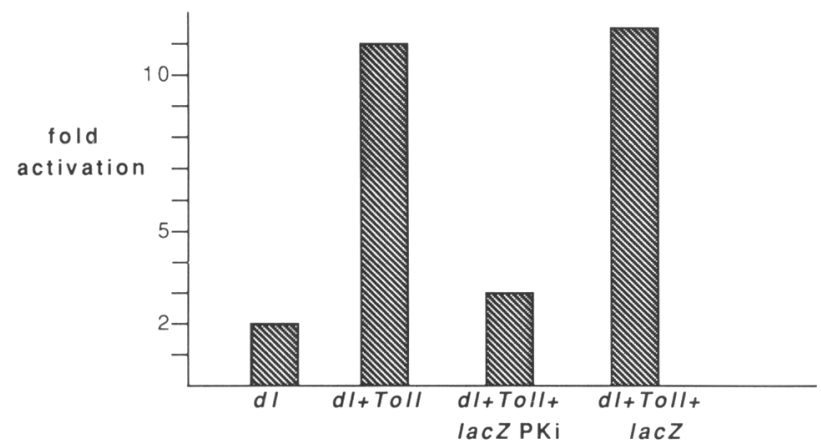

Figure 8. Activity of $d l$ in the presence of Toll and PKi. Schneider cells were cotransfected with the indicated amounts of $d l$ and Toll expression vectors $(\mu \mathrm{g}), 3.0 \mu \mathrm{g}$ of the zen-CAT200 reporter plasmid, and either $3.6 \mu \mathrm{g}$ of lacZPKi or $3.6 \mu \mathrm{g}$ of actin $l a c Z$. The final concentration of expression vector was adjusted to $7.0 \mu \mathrm{g}$ with the actin $5 \mathrm{C}$ expression vector. Fold activation is presented as the increase in CAT activity relative to a cotransfection containing $7.0 \mu \mathrm{g}$ of actin $5 \mathrm{C}$ expression vector without an insert. negative charge at residue 312 . Might this be sufficient to enhance nuclear localization in the absence of Toll? To address this, the $S$ residue was changed to aspartic acid (D), creating the mutant Act-dlD. A similar mutation has been tested in the rel protein and was found to increase nuclear localization (Mosialos et al. 1991). Schneider cells were transfected with $0.4 \mu \mathrm{g}$ of Act-dlD, fixed, and stained with anti-dl antibodies as described above. In contrast to cells transfected with Act-dl, which had primarily cytoplasmic staining, cells transfected with Act-dlD displayed diffuse staining of both the cytoplasm and the nucleus (Fig. 9b, panel C). This pattern was unaffected by cotransfection with PKA or Toll (results not shown). We also assayed the activity of the dlD protein both alone and in the presence of Toll or PKA. The CAT activities presented in Figure 9a show that this mutation results in a protein that was not activated by Toll or PKA and whose activity alone was substantially reduced. This latter result is consistent with that observed with v-rel, where the corresponding $\mathrm{S} \rightarrow \mathrm{D}$ change also reduced the activity of the protein in a CAT assay (Mosialos et al. 1991). These findings suggset that a negative charge at position 312 can enhance nuclear localization, and strengthen the view that Toll (and PKA) function through serine-312.

Finally, to rule out the possibility that any change made in this region might alter $d l$ activity, the proline $(P)$ residue at position 311 was mutated to lysine $(K)$. In the PKA consensus sequence this position can be any amino 


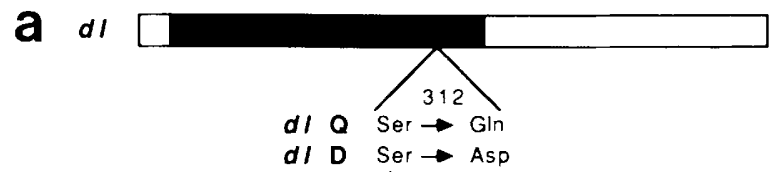

\begin{tabular}{|c|c|c|c|c|}
\hline \multicolumn{2}{|c|}{ dorsal } & - Toll & + Toll & + PKA \\
\hline \multirow{2}{*}{$w t$} & 0.4 & 5.6 & 40 & 71 \\
\hline & 1.0 & 40 & 121 & 130 \\
\hline \multirow{2}{*}{$Q$} & 0.4 & 2.8 & 5.1 & 6.1 \\
\hline & 1.0 & 16 & 10 & 35 \\
\hline \multirow{2}{*}{ D } & 0.4 & 2.1 & 1.6 & 2.4 \\
\hline & 1.0 & 2.3 & 2.5 & 3.2 \\
\hline
\end{tabular}

b
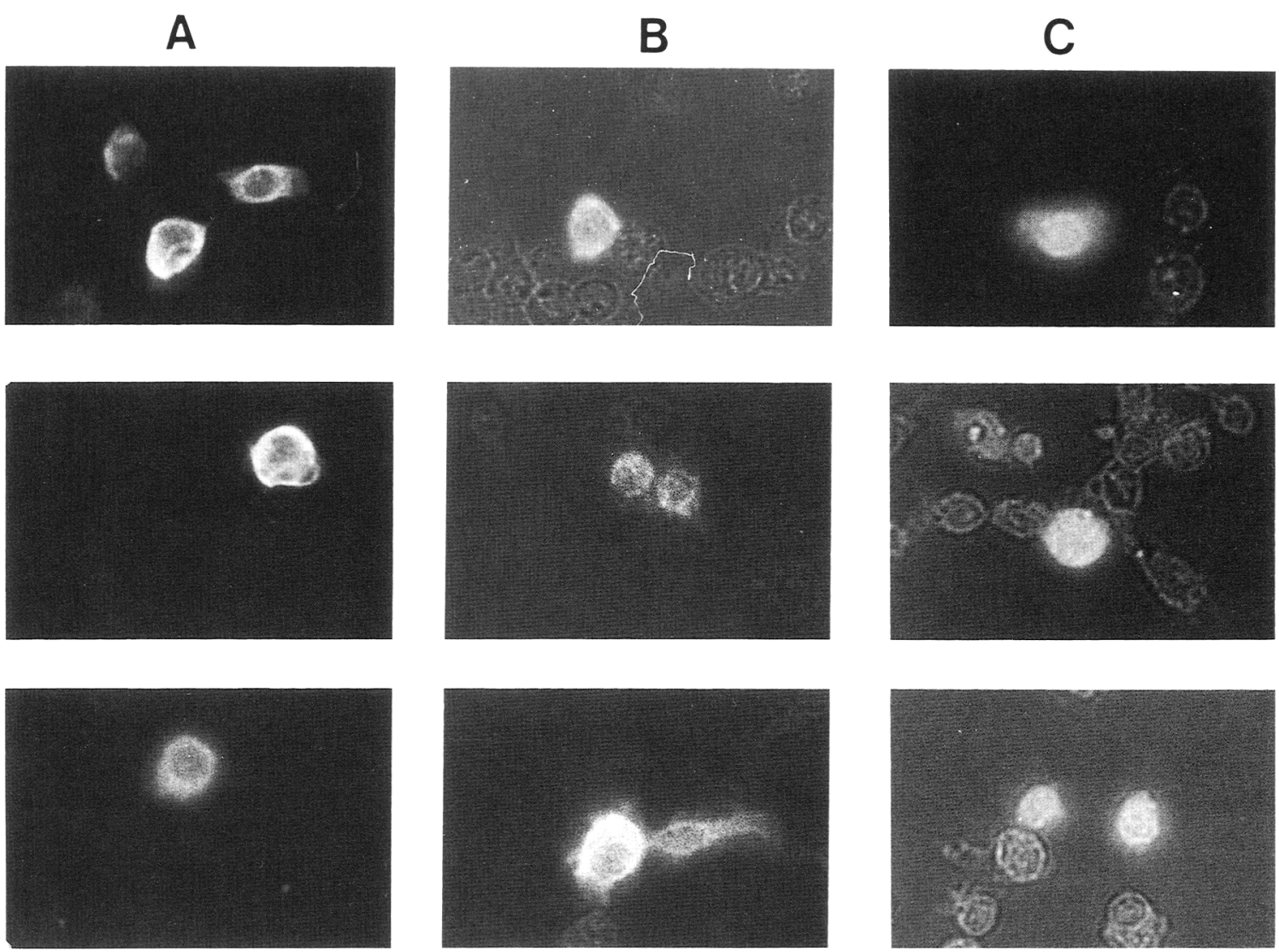

Figure 9. Activity and subcellular localization of a $d l$ phosphorylation site mutant in the presence of Toll and PKA. (a) Schneider cells were cotransfected with the indicated amount of wild-type and mutant $d$ l expression vectors $(\mu \mathrm{g} \mid, 3.0 \mu \mathrm{g}$ of the zen-CAT200 reporter plasmid, and pAct5C, Toll expression vector (+ Toll), or PKA expression vector (+ PKA) to bring the final concentration of expression vector to $5.0 \mu \mathrm{g}$. The activation values are expressed relative to cotransfections containing the actin $5 \mathrm{C}$ vector without an insert. $(b)$ Schneider cells were transfected with $0.4 \mu \mathrm{g}$ of $d l \mathrm{Q}(A), 0.4 \mu \mathrm{g}$ of $d l \mathrm{Q}$ plus $4.6 \mu \mathrm{g}$ of PKA $(B)$, or $0.4 \mu \mathrm{g}$ of $d l \mathrm{D}(C)$ and stained with anti- $d l$ antibodies and TRITC-conjugated secondary antibodies. The $d l Q$ protein accumulates predominantly in the cytoplasm of transfected cells in the presence or absence of Toll or PKA; the dlD protein accumulates in both the cytoplasm and nucleus.

acid (Kemp and Pearson 1990) so changing it should not affect the localization or activity of $d l$ if phosphorylation is the underlying mechanism. This mutant, ActdlRRKS, was cotransfected with zen-CAT200 with or without Act-Tl or Act-PKA, and the resulting CAT ac- tivities were determined. These results (not shown) revealed that the activity of the $d l$ RRKS protein was identical to wild-type $d l$ protein, providing additional support for the idea that phosphorylation of serine-312 by PKA regulates $d l$. 


\section{Discussion}

We have described a cell culture system in which the regulated nuclear transport and activity of the $d l$ protein can be examined. We found that expression of either Toll or PKA together with $d l$ resulted in an increased nuclear localization of $d l$ and an enhancement of the ability of $d l$ to activate CAT expression. We also observed that $d l$ is somewhat more active, and more cells have strong nuclear $d l$ staining when cotransfected with $d l$ plus PKA than when cotransfected with $d l$ plus Toll. This observation supports the notion, discussed below, that PKA is a downstream step in a signal transduction pathway that requires Toll to transmit the signal for $d l$ nuclear localization to $d l$ through PKA.

\section{A model for nuclear localization and activation of $\mathrm{dl}$}

Our results support the model shown in Figure 10 for $d l$ nuclear localization and activation. In this model Toll receives an extracellular signal that is ventrally localized in the perivitelline space of the embryo (Stein et al. 1991). Although the identity of this signal is unknown, it most likely functions by binding to or cleavage of the extracellular domain. Deletion of extracellular domains is a mechanism that can activate some receptors. The epidermal growth factor (EGF) receptor $(\mathrm{c}-e r b \mathrm{~B})$ can be activated by deletion of its extracellular domain and the oncogene v-erbB encodes only the transmembrane and cytoplasmic domain of c-erbB (Downward et al. 1984; Nilsen et al. 1985). Two of the Drosophila dorsal group genes, snake and easter, encode serine proteases that act upstream of Toll (DeLotto and Spierer 1986; Chasan and Anderson 1989), and either could activate Toll by cleaving the extracellular domain. However, the fact that many Toll dominant alleles contain point mutations in the extracellular domain (Schneider et al. 1991) perhaps supports ligand binding as the mechanism for Toll activation. Point mutations may mimic ligand binding by inducing the aggregation of receptors, resulting in their activation. For example, some oncogenic forms of the neu (erbB-2) proto-oncogene contain point mutations in the extracellular domain, and at least one has been shown to lead to an increased aggregation of neu receptors (Weiner et al. 1989). Overexpression has also been shown to activate erbB-2 (DiFiore et al. 1987). We suggest that in Schneider cells, Toll is also activated by overexpression and subsequent aggregation.

Once activated, Toll signals the nuclear localization and activation of $d l$ through PKA. Toll most likely uses cAMP as a second messenger to activate PKA. Although we have no direct evidence for this, work with IL-1R supports this view. The IL-1R protein is a receptor for the interleukin 1 (IL-1) hormone, which is involved in mediating immune and inflammatory responses (Sims et al. 1989). The IL-1R and Toll cytoplasmic domains share extensive sequence similarity (Schneider et al. 1991), suggesting that they could transmit their signals by a similar mechanism. IL-1 has been shown to induce the expression of interleukin-2 receptors (IL-2R) and to induce thymocyte proliferation, in cells that express IL-1R, through stimulation of cAMP production (Shirakawa et al. 1988). IL-1, as well as cAMP and cAMP analogs, has also been shown to activate $\kappa$ light-chain expression by activation of a NF- $\mathrm{KB}$ like DNA-binding protein (Shirakawa et al. 1989). Together, these observations suggest that the signaling pathway from Toll to $d l$ also involves stimulation of cAMP production, leading to the activation of PKA and the phosphorylation of $d l$. Phosphorylated $d l$ is free to move into the nucleus and has an enhanced ability to activate transcription.

Genetic studies have placed two dorsal group genes, tube and pelle, downstream of Toll (Govind and Steward 1991). The proteins encoded by these two genes may be used to help transmit the signal from Toll to $d l$. The tube gene has been cloned, but its sequence reveals nothing about its possible function (Letsou et al. 1991). Because we do not know whether tube and/or pelle are expressed in Schneider cells, we cannot say whether they are absolutely required for this signaling pathway. No genetic

\section{AFTER ACTIVATION}

BEFORE ACTIVATION

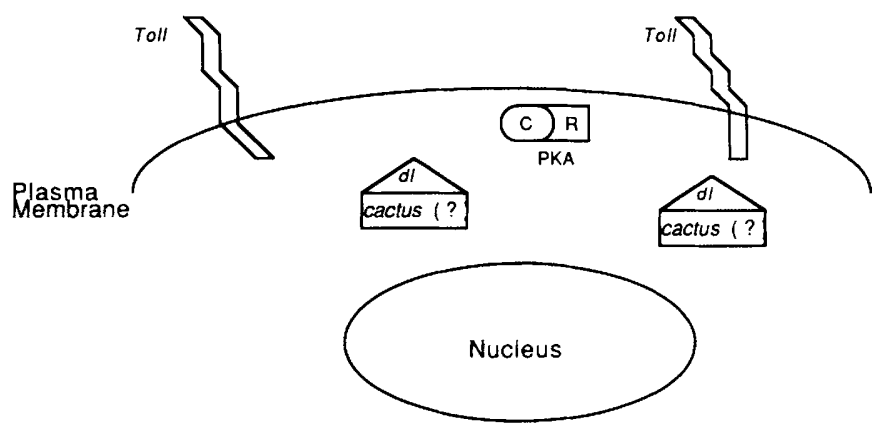

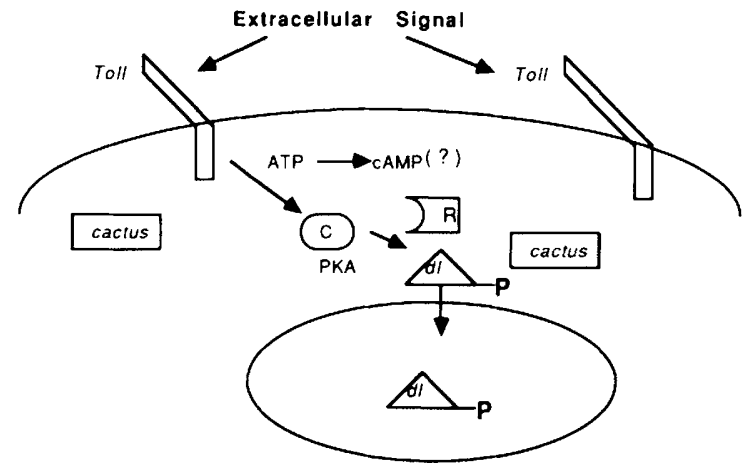

Figure 10. A model for the activation of $d l$ by Toll. Before activation, $d l$ is held in the cytoplasm, and is therefore inactive, through an association with cactus. After Toll receives an extracellular signal, $d l$ is freed from the cytoplasm and activated as a result of phosphorylation by PKA. 
evidence exists implicating PKA in D/V patterning, although this is not surprising given the multiple functions of this protein.

\section{Anchoring of $\mathrm{dl}$ in the cytoplasm}

Like $d l, N F-\kappa B$ is regulated by its subcellular localization, inactive when in the cytoplasm and active when localized in the nucleus (Baeuerle and Baltimore 1988a). $N F-\kappa B$ is retained in the cytoplasm by association with $\mathrm{I}_{\kappa} \mathrm{B}$; and upon disruption of the complex, NF-kB moves into the nucleus (Baeuerle and Baltimore 1988b). Proteins that belong to the I $\mathrm{KB}$ family contain ankyrin repeats (Haskill et al. 1991), and members of the ankyrin family can regulate interactions between membrane and cytoskeletal elements (Lux et al. 1990). Therefore, NF-kB could be held in the cytoplasm owing to its ability to interact with IкB, which could be anchored in the cytoplasm through association with the cytoskeleton. The NF-кB/IкB complex can be destabilized by the phosphorylation of I $k$ B by PKC (Ghosh and Baltimore 1990), indicating that phosphorylation can disrupt this proteinprotein interaction, resulting in the activation of NF- $\mathrm{B}$ in vitro. Such an interaction with a protein anchored in the cytoplasm may also be used to retain $d l$ in the cytoplasm.

NF- $\kappa \mathrm{B}$ can be activated by a variety of agents including viruses, T-cell mitogens, cytokines, bacterial lipopolysaccharides, and DNA-damaging agents (for review, see Baeuerle and Baltimore 1990). NF- $\mathrm{kB}$ is involved in activating the expression of a variety of genes that are required for immune, infection, inflammatory, and acute phase responses in a variety of cell types (Lenardo and Baltimore 1989; Baeuerle and Baltimore 1990; Libermann and Baltimore 1990). Therefore, NF-кB should be responsive to a number of signaling pathways, including $\mathrm{PKC}$. In contrast, $d l$ activity is only required once, for the establishment of polarity in the early embryo; therefore, dl activation probably depends on only one signaling pathway, and the data presented here suggest that this involves phosphorylation of $d l$ by activated PKA. We suggest that a similar activation pathway can be used to activate NF- $\mathrm{B}$ under certain conditions, for example, in response to IL-1. For $d l$, phosphorylation of $d l$ itself is required and alone may be responsible for activating $d l$ by leading to its release from its inhibitor, presumably the cactus protein (see below). However, we cannot rule out that modification of cactus also occurs and plays a role, as we found that the dlQ mutant was still weakly activated by PKA or Toll. The exact mechanism of activation of $d l$ by PKA will not be known until the interaction between $d l$ and cactus is better understood

The cactus gene is one that is required for establishment of $\mathrm{D} / \mathrm{V}$ polarity in the early embryo (Anderson 1987). Unlike the dorsal group genes that give rise to dorsalized embryos when mutated, cactus mutations result in partially ventralized embryos, suggesting that cactus is in some way responsible for inhibiting $d l$ activity (Roth et al. 1989, 1991; Steward 1989). Therefore, cactus has been proposed to perform a function analo- gous to $\mathrm{I}_{\kappa} \mathrm{B}$, anchoring $d l$ in the cytoplasm by forming a dl-cactus complex. This idea is further supported by the finding that cactus, like I $\mathrm{kB}$, contains ankyrin repeats ( $\mathrm{S}$. Kidd, pers. comm.).

In Schneider cells, $d l$ protein is localized in the cytoplasm at low concentrations but is increasingly found in the nucleus as the amount of transfected $d l$ is increased (Rushlow et al. 1989). This observation can be explained in terms of an interaction between $d l$ and cactus because cactus is known to be expressed in Schneider cells /S. Kidd, pers. comm.). Increasing the amount of $d l$ protein expressed in these cells could saturate the endogenous cactus so that at low $d l$ concentrations all $d l$ is bound by cactus. As the amount of $d l$ is increased, there is no free cactus to interact with $d l$, so $d l$ is free to move into the nucleus. In our model for Toll-mediated activation of $d l$, phosphorylation of $d l$ by PKA disrupts the dl-cactus complexes so that $d l$ is free to move into the nucleus even at low concentrations.

\section{Activation of transcription by $\mathrm{dl}$}

In the early embryo, $d l$ influences the expression of several zygotic genes (for review, see Anderson 1987; Rushlow and Arora 1990). Functional binding sites, similar to NF-kB consensus sites, have been identified upstream of zen (Ip et al. 1991) and twist (Jiang et al. 1991; Thisse et al. 1991/genes. Expression of zen is repressed in ventral regions of the embryo (Rushlow et al. 1987) while twist is activated in the ventral-most regions of the embryo (Thisse et al. 1987), suggesting that dl can act as both an activator and repressor. In Schneider cells $d l$ can activate expression from a variety of promoters that do not appear to contain $d 1$-binding sites, including, paradoxically, the zen-CAT200 reporter used here [note that the $d l$ sites in zen are located far upstream of the basal promoter (Ip et al. 1991)]. One reason for this could be the presence of $d l$-binding sites in the CAT reporter plasmid. A possible $d l$-binding site has been found in the pUC vector used here (Thisse et al. 1991). However, a reporter construct containing a deletion of this region is still strongly activated by $d l$ (J.L. Norris and J.L. Manley, unpubl.). A possible explanation for the ability of $d l$ to activate a wide variety of promoters is that the function of $d l$ involves a strong interaction with its target, perhaps a component of the general transcription machinery. This could conceivably allow $d l$ to activate transcription in the absence of $d l$-binding sites, especially when expressed at high levels by transfection. In support of this idea, we have observed a strong and specific functional interaction involving TFIID and $d l$ in cotransfection experiments (J.L. Norris, J. Colgan, and J.L. Manley, unpubl.).

Whatever the mechanism by which $d l$ activates transcription in cultured cells, it is intriguing that both PKA and Toll can enhance this activity independent of their effects on localization. This suggests that phosphorylation of $d l$ increases the ability of the protein to interact either with DNA or with other factors required to activate transcription. Determining the precise effects of 
phosphorylation on $d l$ will require further investigation into the proteins with which $d l$ interacts, in the cytoplasm as well as the nucleus.

\section{Materials and methods}

\section{Recombinant plasmids}

All expression vectors were derived from a plasmid that contains the Drosophila actin 5C promoter and poly(A) site, pAct5CSRS (pAct5C), which has been described in detail (Han et al. 1989). The zen-CAT200 reporter plasmid, pAct-dl, and pAct-dl3 (dl-561) have been described previously by Rushlow et al. (1989). The above constructs and pAct-dl4, pAct-dl5, pAct$d l 6$, and pAct-dl9 were provided by K. Han (Columbia University, New York|. The $d l$ NTS mutants, pAct-dl7 and pAct-dl8, were provided by S. Small. The $d l \mathrm{Q}$, $d l \mathrm{D}$, and $d l \mathrm{RRKS}$ mutants were constructed by site-directed mutagenesis. A $0.65-\mathrm{kb}$ Sacl$E c o R I$ fragment was isolated from pAct-dl and cloned into pBluescript $\mathrm{SK} \mid+$ | (Stratagene), which had been cleaved with SacI and EcoRI. The following oligonucleotides were made: 5'-GCGACGTCCCCAGGATGGAG- $3^{\prime}$ for $d I \mathrm{Q}^{\prime} 5^{\prime}$-CGACGTCCCGATGATGGAGTTACC-3' for $d I D ;$ 5'-CTGCGACGTAAATCGGATGGA-3' for dlRRKS. The oligonucleotides were annealed to uracil containing single-stranded DNA, and synthesis of the second strand was done with T4 DNA polymerase. The resulting clones were screened for sequence that encoded the appropriate amino acid change. Clones containing the desired mutations were isolated and digested with StuI and BstXI to generate a fragment, containing the mutated region, that was used to replace the corresponding wild-type fragment in pAct-dl.

The pAct-Tl expression vector was constructed by isolating a Nsil-KpnI fragment, containing the Toll-coding region, from the Toll cDNA clone [kindly provided by K. Anderson (Schneider et al. 1991)]. The 3' overhang that resulted from cleavage with NsiI was digested with the Klenow fragment of DNA polymerase (Klenow) before cleavage by KpnI. This fragment was inserted into the pAct5C polylinker, adjacent to the actin $5 \mathrm{C}$ promoter, by a filled-in BamHI site and a KpnI site. The pActTlRV mutant was constructed by digesting pAct-TI with EcoRV, which cleaves at one site within Toll and another in the pAct5C polylinker, and removing the 3.6-kb EcoRV-EcoRV fragment to create an in-frame stop after amino acid 274. To construct pAct-T1520, pAct-TIRV was digested with EcoRV and BgIII and ligated with a 2.1-kb SalI-BglII fragment from pAct-Tl to restore the Toll membrane-spanning and cytoplasmic domains. The 5' overhang generated by digestion with SalI was filled in with Klenow to generate an in-frame deletion of amino acids 274-793. The pAct-TIStuI mutant was constructed by digesting pAct-Tl with BglII, NcoI, and StuI to generate a 1.4-kb NcoI-BglII fragment, containing actin $5 \mathrm{C}$ promoter sequences and Toll-coding sequence for amino acids $1-322$, and a 1.9-kb BgIII-StuI fragment that contains Toll-coding sequence for amino acids 323-970. These two fragments were ligated with a 7.0-kb BgIII-Ncol fragment from pAct $5 \mathrm{C}$, containing actin $5 \mathrm{C}$ promoter, actin $5 \mathrm{C}$ poly $(\mathrm{A})$, and pBR322 sequences, which had been cleaved with BglII. The $5^{\prime}$ overhang generated by cleavage with $B g$ III was filled-in with Klenow before digestion with $N c o I$. The pAct- $T 1^{10 b}$ mutant was constructed by digesting pAct- $T l$ with $B g I I I$ and StuI to generate a $7.3-\mathrm{kb}$ BglII$B g l$ II fragment, containing actin $5 \mathrm{C}$ promoter and poly $(\mathrm{A})$ sequences, as well as Toll-coding sequence for amino acids $1-322$, and a 1.6-kb BgIII-StuI fragment that contains Toll-coding sequence for amino acids 970-1097. These fragments were ligated with a BglII-StuI fragment, containing Toll-coding sequence for amino acids $323-969$, from the $T 1^{10 b}$ cDNA clone (kindly provided by K. Anderson| to replace the wild-type sequence with the sequence encoding a cysteine to tyrosine change at amino acid 779 .

The pActPKA expression vector was constructed by cleaving the PKA cDNA clone (kindly provided by D. Kalderon /Columbia University) with $X b a I$, filling in the $5^{\prime}$ overhang with Klenow, and digesting with KpnI. A l.1-kb KpnI-XbaI fragment, containing the PKA-coding sequence, was inserted into the pAct5C polylinker by digesting pAct5C with KpnI and EcoRV. The pAct-lacZPKi expression vector was provided by M.E. Lane [Columbia University).

\section{DNA transfection and transient expression assay}

Drosophila Schneider L2 cells were grown and transfected as described previously (Han et al. 1989). Each transfection contained $5.0 \mu \mathrm{g}$ of expression vector consisting of the indicated amounts of $d l$, Toll, or PKA expression vectors and variable amounts of pAct5C to bring the total amount of expression vector to $5.0 \mu \mathrm{g}$. A total of $10 \mu \mathrm{g}$ of DNA was used for each transfection, so the remaining $5.0 \mu \mathrm{g}$ of DNA consisted of $2.0 \mu \mathrm{g}$ copia long terminal repeat (LTR)-lacZ as an internal control and $3.0 \mu \mathrm{g}$ of the zen-CAT200 reporter plasmid. All transfections were performed in duplicate, and $\beta$-galactosidase and CAT activities were measured as described previously (Han et al. 1989). The CAT activities presented represent the average of several independent transfections.

Transfections that included the lacZPKi expression vector contained $0.4 \mu \mathrm{g}$ of $d l$ expression vector, $3.0 \mu \mathrm{g}$ of Toll expression vector, and $2.0-3.6 \mu \mathrm{g}$ of lacZPKi expression vector. The total amount of expression vector was adjusted to $7.0 \mu \mathrm{g}$ with pAct5C. A total of $12.0 \mu \mathrm{g}$ of DNA, including $2.0 \mu \mathrm{g}$ of copia LTR-lacZ and $3.0 \mu \mathrm{g}$ of zen-CAT200, was used in each transfection. Cells were harvested and protein extracts were prepared as described (Han et al. 1989). The same amount of extract from each sample was used in a CAT assay. A $\beta$-galactosidase assay was performed to ensure that protein was being expressed in approximately equal amounts. Three independent transfections were performed in duplicate, and all gave similar results.

\section{Staining of cells}

Schneider cells were transfected as described above, and $48 \mathrm{hr}$ after transfection the cells were fixed on plates with formaldehyde. The cells were blocked with $10 \%$ BSA, stained with antidl primary antibodies [provided by C. Rushlow and M. Levine [Rushlow et al. 1989)], washed twice with washing and dilution buffer (1\% BSA, $0.5 \mathrm{M} \mathrm{NaCl}$, and $0.1 \%$ Tween 80 in PBS), and stained with TRITC-conjugated secondary antibodies.

\section{Acknowledgments}

We are grateful to K. Anderson, K. Han, D. Kalderon, M.E. Lane, and S. Small for providing plasmids, and to $M$. Levine and C. Rushlow for providing antibodies. We thank D. Kaldron, M. Levine, K. Han, J. Colgan, D. Read, M.E. Lane, and J. Wu for advice and discussion, D. Kalderon for comments on the manuscript, and $\mathrm{S}$. Kidd for communicating results prior to publication. This work was supported by a predoctoral training grant from the National Institutes of Health (NIH) to J.L.N. and NIH grant GM37971 to J.L.M.

The publication costs of this article were defrayed in part by payment of page charges. This article must therefore be hereby 
marked "advertisement" in accordance with 18 USC section 1734 solely to indicate this fact.

\section{References}

Anderson, K.V. 1987. Dorsal-ventral embryonic pattern genes of Drosophila. Trends Genet. 3: 91-97.

- 1989. Drosophila: The maternal contribution. In Genes and embryos (ed. D.M. Glover and B.D. Hanes), pp. 1-37. IRL Press, Oxford, England.

Anderson, K.V. and C. Nüsslein-Volhard. 1986. Dorsal-group genes of Drosophila. In Gametogenesis and the early embryo (ed. J.Gall), pp. 177-194. Alan R. Liss, New York.

Anderson, K.V., G. Jürgens, and C. Nüsslein-Volhard. 1985a. Establishment of dorsal-ventral polarity in the Drosophila embryo: Genetic studies on the role of the Toll gene product. Cell 42: 779-789.

Anderson, K.V., L. Bokla, and C. Nüsslein-Volhard. 1985b. Establishment of dorsal-ventral polarity in the Drosophila embryo: The induction of polarity by the Toll gene product. Cell 42: 791-798.

Baeuerle, P.A. and D. Baltimore. 1988a. Activation of DNAbinding activity in an apparently cytoplasmic precursor of the NF-кB transcription factor. Cell 53: 211-217.

1988b. IкB: A specific inhibitor of the NF- $\kappa B$ transcription factor. Science 242: 540-546.

- 1990. The physiology of the NF- $\mathrm{kB}$ transcription factor. Hormonal regulation of transcription. Mol. Aspects Cell. Regul. 6: 409-432.

Chasan, R. and K.V. Anderson. 1989. The role of easter, an apparent serine protease, in organizing the dorsal-ventral pattern of the Drosophila embryo. Cell 56: 391-400.

Cheng, H.C., S.M. Van Pattern, A.J. Smith, and D.A. Walsh. 1985. A active twenty-amino-acid-residue peptide derived form the inhibitor protein of the cyclic AMP-dependent protein kinase. Biochem. I. 231: 655-661.

DeLotto, R. and P. Spierer. 1986. A gene required for the specification of dorsal-ventral pattern in Drosophila appears to encode a serine protease. Nature 323: 688-692.

DiFiore, P.P., J.H. Pierce, M.H. Kraus, O. Segatto, C.R. King, and S.A. Aaronson. 1987. erbB-2 is a potent oncogene when overexpressed in NIH/3T3 cells. Science 237: 178-182.

Downward, J., Y. Yorden, E. Mayes, G. Scrace, N. Totly, P. Stockwell, A. Ullrich, J. Schlessinger, and M.D. Waterfield. 1984. Close similarity of epidermal growth factor receptor and v-erb-B oncogene protein sequences. Nature 307: 521 527.

Erdélyi, M. and J. Szabad. 1989. Isolation and characterization of dominant female sterile mutations of Drosophila melanogaster I. Mutations on the third chromosome. Genetics 122: $111-127$

Ghosh, S. and D. Baltimore. 1990. Activation in vitro of NF-kB by phosphorylation of its inhibitor ІкB. Nature 344: 678682.

Ghosh, S., A.M. Gifford, L.R. Riviere, P. Tempst, G.P. Nolan, and D. Baltimore. 1990. Cloning of the p50 DNA binding subunit of NF-kB: Homology to rel and dorsal. Cell 62: 1019-1029.

Govind, S. and R. Steward. 1991. Dorsoventral pattern formation in Drosophila: Signal transduction and nuclear targeting. Trends Genet. 7: 119-125.

Han, K., M.S. Levine, and J.L. Manley. 1989. Synergistic activation and repression of transcription by Drosophila homeobox proteins. Cell 56: 573-583.

Hashimoto, C., K.L. Hudson, and K.V. Anderson. 1988. The Toll gene of Drosophila, required for dorsal-ventral embryonic polarity, appears to encode a transmembrane protein. Cell 52: $269-279$.

Hashimoto, C., S. Gerttula, and K.V. Anderson. 1991. Plasma membrane localization of the Toll protein in the syncytial Drosophila embryo: Importance of transmembrane signaling for dorsal-ventral pattern formation. Development 111: 1021-1028.

Haskill, S., A.A. Beg, S.M. Tompkins, I.S. Morris, A.D. Yurochko, A. Johannes-Sampson, K. Mondal, P. Ralph, and A.S. Baldwin. 1991. Characterization of an immediate-early gene induced in adherent monocytes that encodes IKB-like activity. Cell 65: 1281-1289.

Ip, Y.T., R. Kraut, M. Levine, and C.A. Rushlow. 1991. The dorsal morphogen is a sequence-specific DNA-binding protein that interacts with a long-range repression element in Drosophila. Cell 64: 439-446.

Jiang, J., D. Kosman, Y.T. Ip, and M. Levine. 1991. The dorsal morphogen gradient regulates the mesoderm determinant twist in early Drosophila embryos. Genes \& Dev. 5: $1881-$ 1891.

Kalderon, D. and G.M. Rubin. 1988. Isolation and characterization of Drosophila cAMP-dependent protein kinase genes. Genes \& Dev. 2: 1539-1556.

Keith, F.J. and N.J. Gay. 1990. The Drosophila membrane receptor Toll can function to promote cellular adhesion. EMBO I. 9: 4299-4306.

Kemp, B.E. and R.B. Pearson. 1990. Protein kinase recognition sequence motifs. Trends Biochem. Sci. 15: 342-346.

Kemp, B.E., H. Cheng, and D.A. Walsh. 1988. Peptide inhibitors of cAMP-dependent protein kinase. Methods Enzymol 159: 173-185.

Kieran, M., V. Blank, F. Logeat, I. Vandekerckhove, F. Lottspeich, O. Le Bail, M.B. Urban, P. Kourilsky, P.A. Baeuerle, and A. Israël. 1990. The DNA binding subunit of NF- $\kappa B$ is identical to factor $\mathrm{KBFl}$ and homologous to the rel oncogene product. Cell 62: 1007-1018.

Lenardo, M.J. and D. Baltimore. 1989. NF-kB: A pleiotropic mediator of inducible and tissue-specific gene control. Cell 58: 227-229.

Letsou, A., S. Alexander, K. Orth, and S.A. Wasserman. 1991. Genetic and molecular characterization of tube, a Drosophila gene maternally required for embryonic dorsoventral polarity. Proc. Natl. Acad. Sci. 88: 810-814.

Libermann, T.A. and D. Baltimore. 1990. Activation of interleukin- 6 gene expression through the NF- $\mathrm{kB}$ transcription factor. Mol. Cell. Biol. 10: 2327-2334.

Lopez, J.A., D.W. Chung, K. Fujikawa, F.S. Hagen, T. Papayannopoulou, and G.J. Roth. 1987. Cloning of the $\alpha$ chain of human platelet glycoprotein Ib: A transmembrane protein with homology to leucine-rich $\alpha_{2}$-glycoprotein. Proc. Natl. Acad. Sci. 84: 5615-5619.

Lux, S.E., K.M. John, and V. Bennett. 1990. Analysis of cDNA for human erythrocyte ankyrin indicates a repeated structure with homology to tissue-differentiation and cell-cycle control proteins. Nature 344: 36-42.

Mosialos, G., P. Hamer, A.J. Capobianco, R.A. Laursen, and T.D. Gilmore. 1991. A protein kinase-A recognition sequence is structurally linked to transformation by $\mathrm{p} 59^{\mathrm{v}-\mathrm{rel}}$

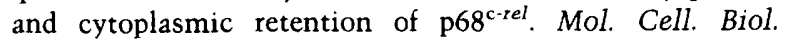
11: $5867-5877$.

Nilsen, T.W., P.A. Maroney, R.G. Goodwin, F.W. Rottman, L.B. Crittenden, M.A. Raines, and H. Kung. 1985. c-erbB activation in ALV-induced erythroblastosis: Novel RNA processing and promotor insertion result in expression of an aminotruncated EGF receptor. Cell 41: 719-726. 
Roth, S., D. Stein, and C. Nüsslein-Volhard. 1989. A gradient of nuclear localization of the dorsal protein determines dorsoventral pattern in the Drosophila embryo. Cell 59: 1189 1202.

Roth, S., Y. Hiromi, D. Godt, and C. Nüsslein-Volhard. 1991. cactus a maternal gene required for proper formation of the dorsoventral morphogen gradient in Drosophila embryos. Development 112: 371-388.

Rushlow, C. and K. Arora. 1990. Dorsal-ventral polarity and pattern formation in Drosophila. Sem. Cell Biol. 1: 173-184.

Rushlow, C., M. Frasch, H. Doyle, and M. Levine. 1987. Maternal regulation of zenknüllt: A homeobox gene controlling differentiation of dorsal tissues in Drosophila. Nature 330: $583-586$

Rushlow, C.A., K. Han, J.L. Manley, and M. Levine. 1989. The graded distribution of the dorsal morphogen is initiated by selective nuclear transport in Drosophila. Cell 59: 11651177.

Schneider, D.S., K.L. Hudson, T. Lin, and K.V. Anderson. 1991. Dominant and recessive mutations define functional domains of Toll, a transmembrane protein required for dorsalventral polarity in the Drosophila embryo. Genes \& Dev. 5: 797-807.

Shirakawa, F., U. Yamashita, M. Chedid, and S.B. Mizel. 1988. Cyclic AMP-an intracellular second messenger for interleukin 1. Proc. Natl. Acad. Sci. 85: 8201-8205.

Shirakawa, F., M. Chedid, J. Suttleo, B.A. Pollok, and S.B. Mizel. 1989. Interleukin 1 and cyclic AMP induce $\kappa$ immunoglobulin light-chain expression via activation of an NF-кB-like DNA binding protein. Mol. Cell. Biol. 9: 959-964.

Sims, J.E., B. Acres, C.E. Grubin, C.J. McMahan, J.M. Wignall, C.J. March, and S.K. Dower. 1989. Cloning the interleukin 1 receptor form human $\mathrm{T}$ cells. Proc. Natl. Acad. Sci. 86: 8946-8950.

Stein, D., R. Siegfried, E. Vogelsang, and C. Nüsslein-Volhard. 1991. The polarity of the dorsoventral axis in the Drosophila embryo is defined by an extracellular signal. Cell 65: 725735.

Steward, R. 1987. Dorsal, an embryonic polarity gene in Drosophila, is homologous to the vertebrate proto-oncogene, c-rel. Science 238: 692-694.

1989. Relocalization of the dorsal protein from the cytoplasm to the nucleus correlates with its function. Cell 59: 1179-1188.

Steward, R., S.B. Zusman, L.H. Huang, and P. Schedl. 1988. The dorsal protein is distributed in a gradient in early Drosophila embryos. Cell 55: 487-495.

Thisse, B., C. Stoetzel, M. El Messal, and F. Perrin-Schmitt. 1987. Genes of the Drosophila maternal dorsal group control the specific expression of the zygotic gene twist in presumptive mesodermal cells. Genes \& Dev. 1: 709-715.

Thisse, C., F. Perrin-Schmitt, C. Stoetzel, and B. Thisse. 1991. Sequence-specific transactivation of the Drosophila twist gene by the dorsal gene product. Cell 65: 1191-1201.

Walsh, D.A. and D.B. Glass. 1991. Utilization of the inhibitor protein of adenosine cyclic monophosphate-dependent protein kinase, and peptides derived from it, as tools to study adenosine cyclic monophosphate mediated cellular processes. Methods Enzymol. 201: 304-317.

Weiner, D.B., J. Liu, J.A. Cohen, W.V. Williams, and M.I. Green. 1989. A point mutation in the neu oncogene mimics ligand induction of receptor aggregation. Nature 339: 230-231. 


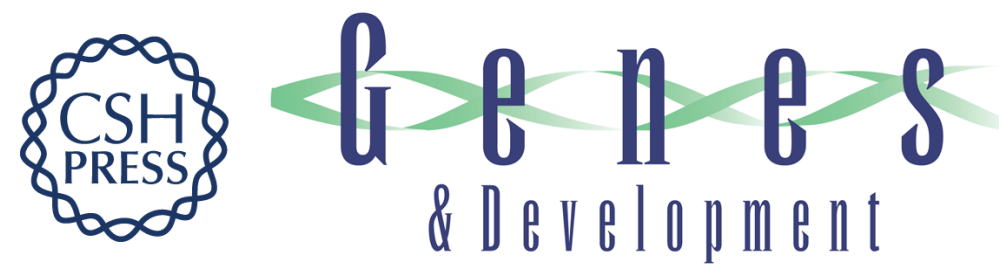

\section{Selective nuclear transport of the Drosophila morphogen dorsal can be established by a signaling pathway involving the transmembrane protein Toll and protein kinase $A$.}

$\mathrm{J}$ L Norris and J L Manley

Genes Dev. 1992, 6:

Access the most recent version at doi:10.1101/gad.6.9.1654

References This article cites 50 articles, 18 of which can be accessed free at: http://genesdev.cshlp.org/content/6/9/1654.full.html\#ref-list-1

License

Email Alerting Service

Receive free email alerts when new articles cite this article - sign up in the box at the top right corner of the article or click here.

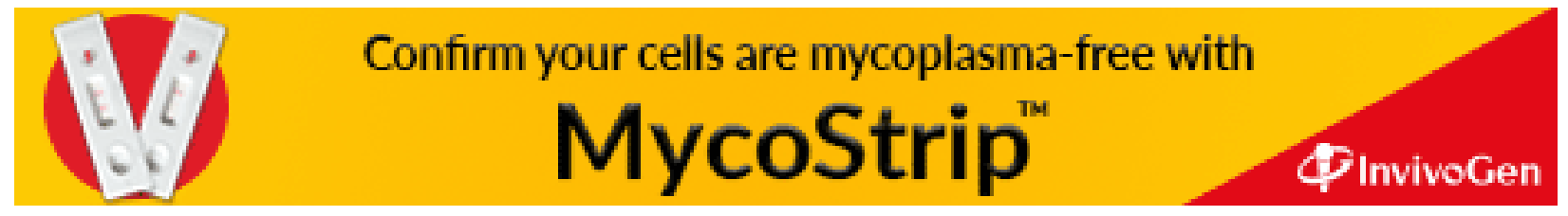

